Tjaša Markežič Prva gimnazija Maribor Slovenija tjasa.markezic@prva-gimnazija.org
DOI:https://doi.org/10.18485/slovenika.2020.6.1.3

UDK: 821.163.6:929 Габорович H.

821.163.6:929 Глазер А.

821.163.6:929 Рајнер М.

Znanstveni članek

\title{
Po poti izgnanstva s slovenskimi književnicami: od Spodnje Štajerske do Srbije
}

\section{Povzetek}

Nemška okupacija dela slovenskega ozemlja v aprilu 1941 je zaznamovala življenja mnogo Slovencev. Okupator je prišel na Spodnjo Štajersko s ciljem, da jo čim prej ponemči. Vse, ki bi jih pri tem načrtu lahko ovirali, so nacisti nameravali izgnati z okupiranega področja. Med žrtvami so bile tudi slovenske književnice, ki so s svojim poklicem, literarnim ustvarjanjem in narodno zavestjo motile okupatorja pri njegovih namenih. Za organizacijo izgona so nacisti najprej ustanovili preseljevalni štab v Mariboru in njemu podrejene organe, za tem pa uredili zbirna taborišča v različnih krajih Spodnje Štajerske. V Mariboru so $v$ taborišče za izgnance preuredili del meljske vojašnice, od tam pa so jih namenili $v$ različne kraje $v$ Srbiji.

Ključne besede: nacizem, Spodnja Štajerska, slovenski književniki, meljsko zbirno taborišče, izgnanstvo

\section{0 uvod}

$\checkmark$ prispevku bomo predstavili pot treh slovenskih književnic s Spodnje Štajerske v času okupacije skozi meljsko vojašnico v Mariboru, ki je $v$ obdobju od 17. aprila do konca julija v letu 1941 služila kot zbirno taborišče za bodoče izgnance, do Srbije. Meljska kasarna je bila le eno od zbirnih taborišč na Spodnjem Štajerskem, namenjenih tistim, ki jih je okupator nameraval izgnati. Po aretacijah se je $v$ njej znašlo veliko slovenskih izobražencev, ki so bili za naciste moteči. Mednje so zaradi poklicne usmerjenosti, kulturnega udejstvovanja ali literarnega ustvarjanja v slovenščini sodile tudi slovenske književnice. V prispevku se osredotočamo na zgodbe Nade Gaborovič, Mete Rainer in Alenke Glazer. O izgonu slovenske inteligence in drugih je maja 1941 poročal 
Slovenski poročevalec, sezname izgnancev pa so objavljali tudi drugi slovenski časniki, ki so izhajali med drugo svetovno vojno. 0 dogajanju pričajo leposlovna dela književnic, ki se navezujejo na prisilno bivanje v zbirnem taborišču in izgon v Srbijo.

\section{Položaj književnic na Spodnjem Štajerskem v obdobju med obema vojnama}

V prvi jugoslovanski državi je povprečno izšlo skoraj sto izvirnih slovenskih leposlovnih del letno; izhajalo je tudi več časopisov in publikacij. V Mariboru je med obema vojnama živelo in ustvarjalo veliko slovenskih književnikov, a niso predstavljali posebnega literarnega središča z enotnim umetnostnim nazorom (Hartman 1983, 242). Leta 1933 so ustanovili Klub književnikov, katerega cilj je bil pritegniti ustvarjalce iz drugih delov Spodnje Štajerske. Toda že leta 1935 so umetniki v Mariboru ustanovili Umetniški klub, ki je združeval poleg književnikov in umetnikov tudi publiciste in gledališke kritike. $S$ tem je nastopilo novo obdobje v kulturnem življenju Maribora, saj je ustanovitev kluba razgibala umetnike in jih spodbudila k ustvarjanju. Ustanovnega zbora so se ob mariborskih umetnikih udeležili še drugi s Spodnje Štajerske (Potočnik 2003, 279-281).

Med obema vojnama so na kulturnem področju delovale različne generacije književnikov. V prvo skupino naj umestimo rojene med 1870 in 1899 , ki so večinoma $v$ zrelih letih dočakali in preživeli prvo svetovno vojno. Književniki, rojeni v 70 . in 80 . letih 19 . stoletja, so bili na višku svojega delovanja že $v$ letih pred vojno. Rojeni v 90 . letih so kulturno delovanje nadaljevali $\vee 20$. in 30 . letih prejšnjega stoletja. $V$ drugo generacijsko skupino umeščamo književnike, rojene med letoma 1900 in 1919. Slednji so grozote prve svetovne vojne doživeli še kot otroci ali dijaki. Literarnemu ustvarjanju so se posvetili po vojni leta 1918, nekateri šele po drugi svetovni vojni.V to skupino lahko umestimo učiteljico Meto Rainer, ${ }^{1}$ ki je drugo svetovno vojno dočakala v Braslovčah $\checkmark$ Savinjski dolini. Tam je tedaj poučevala in živela $v$ skupnem gospodinjstvu z materjo. Spominjala se je, da so ljudje v Braslovčah že 25. marca 1941 priredili demonstracije proti paktu med Tretjim rajhom in Jugoslavijo. Kot drugod so tudi tukaj demonstrirali pod geslom »Bolje rat nego pakt« (Rainer 1974, 286). Svojega delovnega mesta pa se je po okupaciji spominjala takole: Ti naša šola, skromni hram prosvete, | zdaj shajališče tujih policajev! | Čez noč postala si nam »Most vzdihljajev«, | ker nismo in ne bomo marionete! Hkrati je iz pesmi mogoče zaznati tudi misel na upor proti okupatorju (Rainer 2004, 10). Rainerjeva pred drugo

\footnotetext{
${ }^{1}$ Meta Rainer (1904-1995) se je rodila na Ptujski Gori.Po končanem učiteljišču v Ljubljani je službovala kot učiteljica. Po drugi svetovni vojni je diplomirala na Višji pedagoški šoli v Ljubljani, nato pa do upokojitve delovala kot predmetna učiteljica (Buttolo in dr. 1996, 382).
} 
svetovno vojno ni izdala nobenega leposlovnega dela v knjižni obliki, prav tako njenih prispevkov nismo zasledili v tisku. Njena literarna dela so bila objavljena $\vee 60$. letih 20. stoletja in kasneje.

V zadnjo skupino umeščamo avtorje, rojene med 1920 in 1929. Ti književniki prve svetovne vojne niso doživeli, z literarnim ustvarjanjem pa so še kot dijaki ali študentje začenjali $v$ zadnjih letih pred drugo svetovno vojno. $S$ pisateljevanjem se je kot mlada srednješolka ukvarjala v Mariboru rojena Nada Gaborovič; ${ }^{2}$ v tem obdobju se je tu rodila tudi Alenka Glazer, ${ }^{3}$ hči Janka Glazerja. Obe sta se $v$ času med obema vojnama šolali v Mariboru in obiskovali tukajšnji gimnaziji. Gaborovičeva je že kot osnovnošolka začutila potrebo po pisanju: »K temu me je silila neka čudna moč. Nekaj se mi je porodilo v glavi, česar nisem mogla spregledati, in sem neutegoma vzela $v$ roke pero ali svinčnik in zapisala. Od prvega razreda dalje sem pozorno spremljala svoje nagnjenje in ga zapisovala«. Nadarjenost za pisanje leposlovja je dokazala kasneje kot dijakinja, saj je pogosto sodelovala na natečajih in bila nagrajena (Žebovec 2007, 129-130). Že konec marca 1941 je v svojih dnevniških zapiskih zgrožena komentirala pakt, sklenjen med Jugoslavijo in Nemčijo. Po njenih besedah so dijaki navdušeno sprejeli državni udar. Ob tem je opozarjala, da so ljudje $v$ Mariboru živeli v negotovosti in pričakovali nemški napad. Kmalu za tem je bil pouk $v$ šolah prekinjen, ljudje so po njenih spominih začeli zapuščati mesto. Ukinitve pouka se je Gaborovičeva prav dobro spominjala. Na mariborski klasični gimnaziji so 1. aprila 1941 dijakom podelili polletna spričevala. Tudi Gaborovičevi so podobno kot nekateri drugi Mariborčani še pred okupacijo nameravali odpotovati iz Maribora, $\mathrm{k}$ enim od avtoričinih starih staršev zunaj mesta. Po njenem pisanju pa tik pred začetkom vojne na Slovenskem, $\checkmark$ prvih dneh aprila, razen vojakov z vlakom nihče ni smel odpotovati; tako so ostali priklenjeni na Maribor (Gaborovič 2003, 31-47). Alenka Glazer (2016) pa se je spominjala očetove prisege takratnemu mariborskemu županu tik pred izbruhom vojne, da ne bodo zapustili mariborske občine. Janko Glazer je kot ravnatelj knjižnice dano obljubo držal, so se pa zato preostali člani družine 6. aprila 1941 umaknili v Ruše. Glazerjeva se spominja, da so nekateri »v Mariboru z naslado pričakovali naciste in Hitlerja«.

\footnotetext{
${ }^{2}$ Nada Gaborovič, roj. Kropej (1924-2006) v Mariboru, kjer je obiskovala gimnazijo. Njeno šolanje je prekinil začetek druge svetovne vojne, ko so njo in njeno družino izgnali $\checkmark$ Srbijo. Po vojni je študirala slavistiko v Ljubljani in nato delovala kot profesorica na gimnaziji v Mariboru (Buttolo in dr. 1996, 103).

${ }^{3}$ Alenka Glazer se je rodila leta 1926 v Mariboru. Diplomirala je iz jugoslovanske književnosti in slovenščine na Filozofski fakulteti v Ljubljani; na isti fakulteti je študirala tudi umetnostno zgodovino. Bila je višja predavateljica novejše slovenske in mladinske književnosti na mariborski Pedagoški akademiji (Buttolo in dr. 1996, 109). Umrla je leta 2020.
} 
Na območju, kjer so živele omenjene književnice, je bil v obdobju med obema vojnama prisoten nemški vpliv. Po štetju prebivalstva iz leta 1921 naj bi na Slovenskem živelo 41.514 Nemcev (Biber 1966, 20). Načrtno ponemčevanje na slovenskem Štajerskem se je širilo zlasti na socialno odvisne in nemštvu podrejene sloje prebivalstva. Osrednje mesto pri tem je zavzemal Maribor, kjer je bila nemška narodnostna manjšina številčno, socialno in gospodarsko najmočnejša. Poleg tega pa je bila tudi najbolje organizirana, $z$ bogato politično in kulturno tradicijo ter močno poudarjeno narodno zavestjo. Predvsem $v$ nacionalsocializmu so Nemci na Spodnjem Štajerskem videli tisto gibanje, ki je po svoji stanovski, kulturni in politični usmeritvi zastopalo ideje, kakršne so se med Nemci v Mariboru širile že pred prvo svetovno vojno. Pomembno vlogo je imela organizacija Kulturbund, ki se je na Slovenskem razmahnila šele po 1931. Kmalu je postalo očitno, da je bila kulturno-prosvetna dejavnost Kulturbunda le krinka, pod katero so se skrivala politična stremljenja s širjenjem nacističnih idej in konceptov $v$ povezavi z nacističnimi ustanovami v Avstriji in Nemčiji. Vodstvo zveze je želelo odvrniti od sebe odgovornost za okrepljeno nacistično delovanje, zato so leta 1935 razpustili vse svoje organizacije po državi. Z ukinitvijo Kulturbunda v Mariboru nemško narodnostno gibanje ni nehalo delovati, temveč se je legaliziralo $v$ nemških kulturnih, športnih, cerkvenih, družabnih in drugih društvih. Oktobra 1939 so jugoslovanske oblasti dovolile obnovo Kulturbunda. Slovensko prebivalstvo v Mariboru je to sprejelo $z$ ogorčenjem in je nenehno protestiralo proti njegovemu delovanju, zlasti zato, ker slovenska društva zaradi splošne prepovedi zborovanj niso mogla delovati. Po napadu Nemčije na Poljsko septembra 1939 so postali upi Nemcev v Mariboru za uresničitev imperialističnih teženj še realnejši. Sestavljen je bil seznam Nemcem sovražnih Mariborčanov; med njimi so prevladovali Maistrovi borci, člani Sokola, pripadniki nekdanje Narodne odbrane in komunisti. To delo so opravljali člani Kulturbunda in vohunska mreža, ki sta jo vzpostavili varnostna služba ter nemška vojaška obveščevalna služba. Tako je nemška manjšina pripravila vse potrebno za "ponovno osvoboditev« Maribora in preostale slovenske Štajerske (Žnidarič 1997, 37-44).

\section{Začetek druge svetovne vojne in okupacija Spodnje Štajerske}

Slovensko ozemlje je po napadu Nemčije in Italije na Jugoslavijo 6. aprila 1941 postalo operacijsko območje dveh sovražnih armad. S severa in severovzhoda je prodirala 2 . nemška armada, z zahoda pa 2. italijanska. Obe armadi sta prve dni vojne prodirali počasi in se bojevali predvsem na obmejnem območju. Nemška vojska je že prvi dan vojne zavzela Prekmurje, 8. aprila pa še območje do Drave z mesti Maribor, Ptuj, Ormož in Ljutomer, italijanska pa zgornjesavsko dolino do Jesenic. 
11. aprila sta obe vojski prodrli v notranjost Slovenije; čez tri dni je bilo zasedeno vse slovensko ozemlje. Jugoslovanska vojska je 17. aprila kapitulirala. Po zasedbi ozemlja so nemška, italijanska in madžarska vojska, ki je prišla v Prekmurje 16. aprila, na zasedenih območjih uvedle vojaško upravo. Na večini nemškega zasedbenega ozemlja v Sloveniji pa je nemška vojaška uprava nehala delovati še pred kapitulacijo jugoslovanske vojske. Nemški okupator je svoj del zasedenega ozemlja razdelil v dve začasni pokrajinski upravni enoti: Spodnjo Štajersko s središčem v Mariboru in "zasedena območja Koroške in Kranjske« s središčem na Bledu. Civilna uprava na Spodnjem Štajerskem je bila vzpostavljena 14. aprila 1941. Nacistični program za uničenje slovenskega naroda kot etnične enote je imel tri bistvene sestavine: množičen izgon Slovencev, množično naselitev Nemcev, hitro in popolno ponemčenje tistega prebivalstva, ki bi ostalo doma. Po smernicah, ki jih je 18. aprila 1941 v Mariboru podpisal državni komisar za utrjevanje nemštva Heinrich Himmler, naj bi od maja do oktobra 1941 izgnali od 220.000 do 260.000 Slovencev oz. vsakega tretjega Slovenca, ki je takrat živel na nemškem zasedbenem območju. To v vojnem času ni bilo uresničljivo že zaradi transportnih omejitev. Kljub temu pa so načrt začeli uresničevati z vso zagnanostjo (Ferenc 1997, 5-13). Nosilce narodne misli v zasedenih krajih je okupator sklenil najprej onemogočiti, da ne bi ovirali ponemčevanja. Med narodno zavednimi Slovenci so bili v prvi vrsti slovenski izobraženci. Ob vdoru na slovensko ozemlje so nacisti že imeli zbrane podatke o politični in narodni pripadnosti tukajšnjega prebivalstva. Te podatke so zbrali s pomočjo razvejane vohunske mreže, ki je bila razširjena zlasti med pripadniki nemške manjšine na Slovenskem (Godeša 1995, 56-58). Že v prvih dneh okupacije so Nemci za izgon slovenskega prebivalstva ustanovili preselitveni štab $\checkmark$ Mariboru ter mu dodali še urad pooblaščenca državnega komisarja za utrjevanje nemštva z nalogo, da zapleni imetje izseljenih Slovencev (Roš 1967,10).Začeli so se popisi prebivalstva in politični ter rasni pregledi, iskanje prostora, kamor naj bi deportirali Slovence ipd. Najprej so ustanovili preseljevalni štab v Mariboru, ki je imel nalogo odstraniti vse tujerodne elemente. Osebje preseljevalnega štaba je bilo iz vrst gestapa, kriminalne policije in varnostne službe, taborišča pa so navadno stražili policisti iz zaščitne policije (Filipčič 2003, 30-31). Štab so sestavljali trije referati. Prvi je popisoval tiste, ki jih je bilo po zadanih smernicah treba izgnati, ter preverjal njihovo narodnost in politično prepričanje. Drugi referat je imel nalogo rasno preiskovati ljudi, predvidene za izselitev, oz. ugotavljati sposobnost za ponemčenje. Tretji referat je moral tehnično izvesti deportacije. Prvi referat je po popisu prebivalstva izdelal ustrezno kartoteko in jo izročil tretjemu referatu. Ta je izdelal sezname in jih izročil poveljnikom policijskih enot, ki so na seznamih napisane osebe pripeljali v zbirna taborišča. Tam so izvedli še osebno preiskavo in rasni pregled (Ferenc 1968, 179-180). Izgon 
naj bi zajel štiri vrste Slovencev: Nemcem sovražne osebe - izobražence in vplivne, narodno zavedne ljudi; priseljence po letu 1914; obmejno prebivalstvo; tiste, ki se ne bi prijavili v raznarodovalne organizacije ali ki jih iz rasnih, političnih ali dednozdravstvenih razlogov vanje ne bi sprejeli (Ferenc 1997, 13).

\section{Slovenske književnice v prvih tednih okupacije}

Slovenski književniki so ob okupaciji doživeli korenito življenjsko spremembo. Ni šlo le za izgubo delovnega mesta, temveč tudi za strah pred izgubo domovanja ali celo življenja, strah pred poniževanjem in mučenjem. Nada Gaborovič se je spominjala, kako je slovenska beseda kmalu po okupaciji v Mariboru izginila z ulic. Narodno zavedne državne uradnike so nacisti takoj razrešili službe, duhovnike pa zaprli. Predvidevala je, da bodo vse zavedne Slovence iz mariborskega okoliša izgnali. Že aprila 1941 je tudi ona vedela, da je v Melju zaprtih precej vojaških in političnih ujetnikov ter vsa inteligenca. Mariborski Nemci in kulturbundovci so se znašali nad slovenskim prebivalstvom. Gaborovičeva je 7. ali 8. maja prišla v Ljubljano in tam preživela en mesec, da je končala razred. V Ljubljani namreč Italijani niso zaprli slovenskih šol. V začetku junija se je vrnila v Maribor, ker je doma imela vse svoje knjige, poleg tega pa s sestro staršev nista želeli pustiti samih. Menila je, da je etično, da se vsi štirje podajo na pot izgnanstva (Gaborovič 2003, 38-45). Alenka Glazer je povedala, da je njen oče Janko Glazer 22. aprila 1941 izgubil službo ravnatelja knjižnice in se pridružil drugim članom družine $v$ Rušah. Vedeli so, da jih bodo nacisti izgnali, ker so jih že iskali v stanovanju v Mariboru (Glazer 2016). Meta Rainer pa je ob spominu na dogajanje v prvi polovici leta 1941 napisala sonet Čas, v katerem je izpovedala svoje strahove in nasprotovanje okupatorju: $V$ katerih je zapisano planetih, | da nad človeštvo bo prišla nevolja, | da pognoje s krvjo se, s trupli polja | na obli zemeljski v usodnih letih? || Ves svet gori v sovražnostih naštetih, | ko da sam vrag priliva zraven olja, | ko da podlegla zli je dobra volja | in da velja beseda le prekletih (Rainer 2004, 4).

Veliko izobražencev se je $v$ takih razmerah $s$ Spodnje Štajerske umaknilo zlasti v Ljubljansko pokrajino ali na podeželje. Tisti, ki so se izognili množičnemu izgonu prvega vala ali pa pred nemškim okupatorjem niso pobegnili v Ljubljansko pokrajino, na Hrvaško ali na podeželje, se niso rešili pred nevarnostjo izgona iz domačih krajev. Slovenskega izobraženstva nacisti iz političnih razlogov niso sprejemali v raznarodovalni organizaciji Štajerska domovinska zveza in Koroška ljudska zveza. Tako si niso mogli pridobiti nemškega državljanstva, stalnega ali na preklic, ki je bilo odvisno od stopnje stalnega ali začasnega članstva $v$ organizaciji. Nečlani so dobili status zaščitencev nemškega rajha. To so bili prebivalci z omejenimi pravicami, ki so jih namenili za izgon ali sterilizacijo (Godeša 1995, 68-69). Mladino pa 
so nacisti začeli vabiti v Hitlerjugend; tudi Nado Gaborovič, ki je bila takrat stara 17 let. S sestro sta vabila odklanjali. Gaborovičeva je kasneje pojasnjevala, da se nista hoteli ponemčiti. Njune starše so vabili v Štajersko domovinsko zvezo, vendar so tudi oni odklanjali pristop iz istega razloga kot sestri (Gaborovič 2003, 38-45). Zaradi ostrega postopanja nacistov z izobraženstvom so se nekateri skušali izogniti nasilju na manj časten, a glede na to, da je bilo ogroženo golo preživetje, po svoje razumljiv način. Začeli so brskati po svojih rodovnikih in iskati prednike, s katerimi bi morda lahko dokazali svoje nemško poreklo, kar bi jih obvarovalo pred izgonom. Tako so tudi nekateri umetniki »odkrili« svoje nemške korenine. Šlo je predvsem za glasbenike in likovnike, saj so se književniki že zaradi jezika težje prelevili iz slovenskih piscev v nemške (Godeša 1995, 69-70).

Vodilno vlogo pri ponemčevanju v Mariboru med okupacijo naj bi imelo okupatorjevo šolstvo. Že 1. aprila 1941 so vse mariborske šole prenehale s poukom. Otroški vrtci in šole naj bi pod nemško okupacijo postali osnovne postojanke za prevzgojo slovenskih otrok in mladine. Zvezno vodstvo Štajerske domovinske zveze je novo nastajajočemu nemškemu šolstvu zastavilo štiri naloge: $v$ deželi morajo biti le nemške šole, $v$ katerih naj pouk poteka samo $v$ nemščini; ne sme biti dvojezičnega šolstva niti manjšinskih šol; delo šol mora biti tesno povezano z delom organizacij Nemške mladine; šola naj postane središče ponemčevalnega dela. Večina učnega kadra, ki ga je okupator postavil na območju Spodnje Štajerske, je bila iz sosednje Avstrije. Podobno kot osnovne je okupator v Mariboru takoj ukinil vse strokovne in srednje šole. Ukinitev slovenskih šol je najbolj prizadela gimnazijce, ki so bili pred maturo. Pod okupacijo je bilo tudi med srednješolskimi profesorji največ Nemcev iz rajha. Nekaj manj je bilo Avstrijcev ter zelo redko kak domačin. Nekatere slovenske profesorje so namreč odpustili, zaprli ali pa so se ti pravočasno umaknili v Ljubljano. Mnoge so kasneje izgnali. Večina slovenskih učiteljev, ki je ostala na svojih mestih, ni simpatizirala z okupatorjem in je slovenskim otrokom pomagala, če se je le dalo (Žnidarič 1997, 113-116).

Nekaj književnikov je kljub težkim razmeram ostalo v Mariboru in drugih krajih Spodnje Štajerske. Preden so jih izgnali, so do njih prišli pozivi k uporu proti okupatorju. Gaborovičeva se v svojem avtobiografskem romanu spominja, da so se zadnje dni junija 1941, torej tik preden so jih z družino odpeljali v meljsko zbirno taborišče in od tam $s$ transportom v Srbijo, pogovarjali z ljudmi, ki so jih obveščali o stanju na frontah in jih pozivali, naj se pripravijo na sodelovanje $v$ boju proti nacizmu. Vedeli so, da bo ta boj potreben, sicer bodo Slovenci kot narod izgubljeni. Gaborovičevi so takrat obljubili pomoč in borbo, razen če bi jih izgnali iz Maribora (Gaborovič 2003, 51). Književniki, ki so ostali na svojih domovih, so lahko le čakali na nadaljnjo usodo, ki jim jo je namenil okupator. 


\section{Aretacije na Spodnjem Štajerskem: kako so jih doživele slovenske književnice}

Še pred prihodom Heinricha Himmlerja v Maribor 18. aprila 1941 so se začele prve aretacije na podlagi seznamov, ki so jih nacisti prinesli s seboj iz Gradca (Godeša 1995, 59-61). V Mariboru so prve aretacije izvedli že v noči na 11. april, po iniciativi kulturbundovcev, prvo večjo akcijo pa so izpeljali štiri dni kasneje, 15. aprila, ko se je znašlo za zapahi kar 300 ljudi. Aretacije za drugi val deportacij so zaključili 12. julija, nadaljevale pa so se še v naslednjih dneh. Izvajali so jih hkrati v mestu in bližnji okolici. 21. julija so nacisti izvedli že deseto akcijo aretacij; še dve akciji sta bili 25. in 26. julija, omejili pa so ju le na mesto Maribor (Žnidarič 1997, 96-104). Kulturbundovci so sodelovali z okupatorjevo policijo in žandarmerijo pri aretacijah. Nacisti so kulturbundovce potrebovali deloma kot tolmače deloma kot vodnike do stanovanj, $v$ katerih so bivali Slovenci, predvideni za izselitev. Pomembni so bili tudi pri političnem ocenjevanju ljudi; poskrbeli so, da so bili seznami daljši predvsem zaradi lastnega interesa po premoženju, ki so ga bodočim deportirancem zaplenili.

Zaradi deportacij in gestapovskih metod so ljudje živeli v nenehnem strahu in napetosti, saj nihče ni vedel, kdaj bodo prišli ponje. Varnostna služba je določila, koga je treba odpeljati, redarstvena policija pa je običajno imela nalogo pobrati ljudi iz stanovanj in jih pripeljati $\vee$ za to določene javne stavbe: vojašnice, jetnišnice, šole ipd. (Škerl 1952/1953, 774-784). Za aretacije so določili pozno večerno ali zelo zgodnjo jutranjo uro, zlasti zato, da so dobili celotno družino zbrano doma. Poleg tega so tisti, ki so jih presenetili in prebudili, s seboj vzeli čim manj (Žnidarič 1976, 3). Glede na spomine književnikov se lahko upravičeno sprašujemo, v koliko primerih je nacistom uspelo presenetiti aretirance. Gaborovičeva je namreč v svojem dnevniku zapisala, da so bili z družino vsako noč pripravljeni, da pridejo po njih, saj so vedeli, da se transporti že vrstijo drug za drugim. Njen zapis ni natančno datiran. Nastal je med 30. junijem in koncem julija 1941 (Gaborovič 2003, 46). Po aretirance so nacisti prišli z obsežnimi formularji in jim postavili vprašanja o vsakršnem možnem imetju, nepremičninah in o bančnih prihrankih; vse so namreč nameravali zaseči (Ostrovška 1981, 40). Aretacije so $v$ Mariboru potekale nemoteno, saj v poročilih komandirjev policijskih čet, ki so aretacije izvajali, ni navedenega nobenega primera upiranja. Vsaka akcija aretacij je zajela več ulic, ki so jih policijske enote povsem zaprle (Žnidarič 1997, 98-101). S policijskimi enotami je $v$ akcijah sodelovalo tudi orožništvo, ki je moralo priskrbeti prevajalce. 
Aretirance so v Mariboru takoj prepeljali v meljsko vojašnico, $v$ drugih krajih Spodnje Štajerske pa v druga zbirna taborišča (Žnidarič 1976, 3). ${ }^{4}$

27. aprila 1941 so v Braslovčah aretirali Meto Rainer in jo odpeljali v celjski Stari pisker (Rainer 1974, 286). Rainerjeva je v spomin na prav ta dan napisala sonet z naslovom 27. 4. 1941. V njem je izrazila bolečino, negotovost in domoljubje: Poslavljamo se od tebe, dolina! | Prebujaš se v pomlad in se razcvetaš. | Mar od življenja si še kaj obetaš, | ko so iztrgali ti hčer in sina? || Mar te ne gane naša bolečina, | da si prav zdaj cvetoče vence spletaš, | solz naših bisere si v krilo vpletaš, | otroke svoje brišeš iz spomina? V sonetu Ločitev pa se ženski lirski subjekt spominja takratnega slovesa od matere: Ko naložili so me za odhod, I si stala, mama, spodaj in jokala, | roke k obrazu bledemu tiščala, | korak ni vedel ti, ne kam ne kod. Znani celjski zapor je $v$ svojih pesmih upodobila kot hladen grob z debelimi zidovi in mračnimi stropi, kjer čas mineva počasi, telesa slabijo in obrazi bledijo zaradi slabih razmer in neprijaznih ječarjev (Rainer 2004: 5-14). Glazerjeve so zaprli nekoliko kasneje, 27. junija 1941 (Ciril 1977, 11). Janko Glazer je po prisilnem odpustu iz Študijske knjižnice previdno, da ga ne bi opazili nemškutarji, ki so mu jih po nemški okupaciji vselili v hišo, skrival knjige na podstrešju pod podnicami med trami. Prijeli so ga, ko je bil ponovno pri tem opravilu na podstrešju in je komaj utegnil položiti podnico na odprtino (Ostrovška 1981, 30). Po preostale družinske člane pa so v Ruše prišli šele kasneje, 4. julija 1941, tik pred transportom (Glazer 2016). 30. junija ob 4. uri zjutraj so nacisti prišli tudi po Nado Gaborovič in njeno družino. Gaborovičeva je nekaj svojih rokopisov takrat dala dvema sosedama. Vojak, ki je prišel po njih, ji je to dovolil, vendar se je zavedala, da lahko rokopise izgubi, če jo bo izdal. S tovornim avtom so jih odpeljali v meljsko kasarno, kjer je srečala tudi mladega literata Milana Lindiča, s katerim sta si pred začetkom vojne dopisovala (Gaborovič 2003, 31-47).

\section{Prisilno bivanje v meljskem zbirnem taborišču}

Prve dni okupacije je nemški okupator po mestih in trgih zapiral ljudi $\vee$ ječe, ki so bile kmalu prenapolnjene. Zato je tretji referat preseljevalnega štaba v Mariboru dobil nalogo ustanavljati in voditi zbirna taborišča za slovenske izgnance. Med prvimi je bilo ustanovljeno zbirno taborišče $v$ meljski vojašnici v Mariboru. Poleg rajhenburškega je bilo to edino pravo zbirno taborišče, druga (Celje, Šmartno pri Slovenj Gradcu, Borl pri Ptuju ...) so bila le prehodna. Iz njih so pošiljali jetnike v Maribor in Rajhenburg (Žnidarič 1997, 96-98). Meljsko kasarno je

\footnotetext{
${ }^{4}$ Zelo znano zbirno taborišče je bilo tudi $\vee$ Rajhenburgu; tja so prepeljali posavskoobsoteljsko prebivalstvo, česar se med drugim spominja Terezija Černelič. Navaja, da so Nemci izgnali celotne vasi; izgon je bil hiter, namestitev in hrana nezadostni, trpeli so lakoto, mraz in pomanjkanje. Tudi ona, podobno kot Gaborovičeva, pove, da so selitev oz. izgon že pričakovali (Milharčič Hladnik 2020, 430).
} 
v zbirno taborišče nemški okupator preuredil kmalu po okupaciji, če upoštevamo sezname jetnikov, ki so datirani s 17. aprilom 1941.V prvih mesecih nemške okupacije je bila meljska kasarna v Mariboru največje preselitveno taborišče na Štajerskem. Zbirno taborišče $v$ Mariboru so nacisti uredili v južnem poslopju meljske vojašnice, $v$ preostalem delu pa je bilo zbirališče za ujete pripadnike vojske Kraljevine Jugoslavije, preden so jih odpeljali $\vee$ ujetniška taborišča $v$ Nemčijo. $\vee$ začetku so taborišče stražili člani Sturmabteilung (SA), Schutzstaffel (SS) in Nationalsozialistisches Kraftfahrkorps (NSKK) z Gornje Štajerske, pozneje pa rezervna policijska četa »Wien«. Po prihodu v taborišče so aretirancem pobrali vse: ključe, žepne nože, vžigalice in druge malenkosti, zlasti pa so iskali zlatnino in nakit. Odvzeli so jim tudi hranilne knjižice in vrednostne papirje. Ni znano, koliko dragocenosti so tako zbrali (Žnidarič 1997, 96-98). Tega se je spominjala Nada Gaborovič. Stvari so ob prihodu v taborišče morali odložiti na tla in čakati na pregled oz. iskanje dragocenih predmetov. Da so iskali res le vredne stvari, dokazuje dejstvo, da niso želeli vzeti poročnega prstana njene matere, ker ni bil zlat; vzeli pa so jim milo (Gaborovič 2003, 47-51).

Zaslišanje Slovencev $v$ taborišču je bilo sestavljeno iz političnega in rasnega pregleda ter zaslišanja. To delo sta opravljali dve komisiji: rasna in politično-gospodarska. Pri rasni komisiji so ugotavljali raso aretirancev in njihove prednike po strani obeh staršev. Po opravljenem pregledu rasne komisije so aretirance poslali k politično-gospodarski komisiji. Ta se je zanimala za zapornikovo preteklost, politične nazore, vero, javno udejstvovanje in gospodarski položaj. Politični kriterij pa je ljudi delil v pet skupin: aktivno prijateljska Nemcem; prijateljska Nemcem; indiferentna; nasprotna Nemcem; aktivno nasprotna Nemcem (Škerl 1952/1953, 777). Zaslišancem so navadno očitali protinemško delovanje in spraševali, $v$ katerih društvih je kdo deloval. Proti večini ujetnikov niso imeli nobenih posebnih obtožb; samo $v$ redkih primerih so internirance lahko obtožili konkretnih prestopkov. Za dokončno določitev njihove usode je bil potreben še en pregled. Po tem so razdelili internirance v tri skupine: A, B in C.V skupino A so prišli tisti, ki so imeli srednješolsko ali višjo izobrazbo, v skupino $B$ tisti, ki po rojstvu niso spadali na Spodnjo Štajersko in še niso bili porazdeljeni v skupino $A, v$ skupino C pa vsi drugi. Skupini A in B so kmalu v celoti izselili. Izpustili so le nekatere internirance iz skupine C. Vsak interniranec je ob odpustu moral podpisati dve izjavi: da bo zvest nemški državljan in da ne bo povedal nič o taborišču. Mnogo teh odpuščenih internirancev je bilo kasneje kljub temu izseljenih (Ferenc 1968, 201-203).

Režim v zbirnem taborišču je bil podoben režimu v nacističnih koncentracijskih taboriščih lažje stopnje. $V$ njih sicer ni bilo krematorijev in plinskih celic, so se pa zato stražarji v taboriščih posluževali drugih oblik nasilja. Aretirance, zlasti izobražence, ki jih je bilo največ, so zasmehovali in poniževali. Še posebej poniževalno so ravnali z duhovniki 
(Žnidarič 1997, 96-98). Posameznike so nacisti za najmanjšo kršitev taboriščnega reda zapirali v bunkerje, kjer so jih tolkli z revolverji, jim zbijali zobe, lomili rebra, jih pretepali. Za tem so jih nekaj dni imeli zaprte na kamnitih tleh, da so jim otekline in podplutbe nekoliko upadle, nato pa so jih premestili v drugo sobo, kjer jih drugi jetniki niso poznali (Ferenc 1968, 198).

Nacisti so dopise in pakete, ki so jih sploh sprejeli, cenzurirali. Jetnikom so bili dovoljeni obiski le izjemoma, $v$ prisotnosti oboroženih stražnikov in z uporabo nemščine $v$ pogovoru (Roš 1967, 50). Ženske so prihajale pred vojašnico in prosile, da bi sprejeli njihove pakete $s$ perilom; $v$ njih so bili tudi priboljški za bodoče izgnance. Nemci so pakete včasih sprejeli, mnogokrat pa ne. $V$ takšne pakete so bila večkrat vtihotapljena sporočila. Tisti, ki niso zunaj imeli nikogar, ki bi jim pošiljal pakete, so jih dobivali od neznanih dobrotnikov (Ostrovška 1981, 41-42). Po besedah Gaborovičeve je bilo v kasarni vsak dan burno in pestro. Že ob prihodu je srečala Milana Lindiča ter gimnazijskega profesorja Franceta Borka. Za ljudi zunaj žične ograje se ni zanimala, saj je menila, da se tudi zanje nihče ni zanimal. Bodoči izgnanci so lahko čez ograjo opazovali vojne ujetnike. Gaborovičeva se spominja navezovanja stikov z njimi. Čez pregrado v taborišču so jim vsak dan metali hrano in cigarete. Vojni ujetniki so jim izročali pisma za svojce, vendar je Gaborovičeva zapisala, da glede na to, kako se je razbohotil »nemški zločinec « po Evropi, dvomi, da bodo pošiljke prišle na želene naslove. Ob izmenjavi hrane in pisem med obema stranema so bili nekateri stražarji bolj, nekateri manj prizanesljivi. Ko so izgnanci vojnim ujetnikom čez ograjo vrgli hlebec kruha, ga je eden od manj prizanesljivih zahteval nazaj in ga z nogo poteptal na tleh (Gaborovič 2003, 47-51).

Jetniki so morali vsako jutro počistiti uradne prostore $v$ kasarni. Tako so nekateri večkrat poskušali brskati po mizah in predalih ter nato $\mathrm{V}$ sobe prinašali polne žepe predmetov, ki so jih nacisti zaplenili zapornikom in jih shranili v pisarniških omarah. Nekega dne pa so odkrili tudi skicirano maršruto transportov $z$ namembno postajo Aranđelovac. To je bila za zapornike nadvse pomembna novica (Roš 1967, 57). Gaborovičevi so pred transportom upali, da se bodo smeli vrniti domov še po nekaj stvari, saj v zmedi in naglici ob aretaciji niso uspeli vzeti vsega, kar so potrebovali. Njihova želja se ni izpolnila, določeni so bili namreč za naslednji transport (Gaborovič 2003, 47-51). Iz družine Glazer je v meljskem taborišču bival le oče; Alenka, njen brat Matija in mati so $\mathrm{v}$ taborišče prišli tik pred odhodom njihovega transporta v Srbijo, s čimer so se izognili vsaj nevzdržnim razmeram in poniževanju v zbirnem taborišču. 


\section{6 »Na topli jug! « - in v srcih ni več mraza}

Ko so nacisti izbirali, popisovali in zapirali ljudi za deportiranje, so iskali tudi prostor, kamor bi jih izgnali. Število Slovencev, ki so jih nameravali izgnati, je bilo zelo visoko, zato vprašanje, kam z njimi, ni bilo enostavno. Že 24. aprila 1941 je šef varnostne policije in varnostne službe Reinhard Heydrich sklical konferenco, ki naj bi razpravljala o izvedbi deportacij Slovencev. Konferenca je bila 6. maja v sejni sobi šefa civilne uprave za Spodnjo Štajersko v Mariboru. Udeležili so se je nemški vojaki, policijski in civilni uradniki iz Berlina, Beograda in Maribora. Vojaški poveljnik za Srbijo Helmuth Förster je kljub močnim pomislekom glede prehrane in nastanitve obljubil, da bo na območje Srbije sprejel toliko Slovencev, kolikor jih bo mogel. Udeleženci konference so predvideli izselitev $v$ treh valovih. Predlog, da bi del Slovencev izselili v Neodvisno državo Hrvaško (dalje NDH), je sam Hitler takrat zavrnil, ker bi Slovenci bili preblizu svoji nekdanji domovini. Förster je naslednjo konferenco sklical 21. maja. Udeleženci so obravnavali vprašanje, ali naj v Beogradu za priseljence ustanovijo sprejemno taborišče. Ugotovili so, da je treba najprej poiskati ustrezne kraje, kamor bodo postavili barake za izgnance. Srbski generalni komite za slovenske izgnance so morali seznaniti s svojimi načrti ter se z njim pogovoriti o nastanitvenih in prehrambnih vprašanjih. Förster je izrekel pripravljenost, da sprejme prve transporte že v juniju 1941. Kmalu po konferenci pa so ugotovili, da razmere $v$ srbskem prostoru še ne omogočajo priselitve 260.000 Slovencev. Tudi datuma za začetek deportaciji še niso mogli predvideti, saj je bilo treba popraviti železniške proge, razstreljene mostove in zgraditi sprejemno taborišče. Lahko bi izvedli prvi val deportacij $\vee$ prvih desetih dneh junija pod pogojem, da se držijo naslednje omejitve: na teden le dva transporta po tristo oseb. Sklenili so tudi, da je oskrba izgnancev izključno stvar Srbov in Slovencev. Začela se je odpirati možnost izgona Slovencev v NDH; da bi razpravljali o tej možnosti, so sklicali še zadnjo konferenco, ki je potekala 4. junija 1941 $\checkmark$ prostorih nemškega poslaništva $v$ Zagrebu. Prisotni so se dogovorili, da bodo deportacije izvedli $v$ treh valih. Določili so tudi čas in obseg vsakega vala. V prvem valu naj bi do 5. julija 1941 izgnali s slovenske Štajerske 5000 Slovencev neposredno v Srbijo, le katoliške duhovnike naj bi izgnali $v \mathrm{NDH}$, od koder bi preselili enako število pravoslavnih duhovnikov z družinami vred. V 2. valu naj bi od 10. julija do 30. avgusta 1941 izgnali v NDH okoli 25.000 Slovencev, ki so se po letu 1914 naselili na slovenskem Štajerskem. Obenem naj bi iz NDH v Srbijo izgnali enako število Srbov. V 3. valu naj bi od 15. septembra do 31. oktobra v NDH izgnali okoli 65.000 slovenskih kmetov z obmejnih predelov slovenske Štajerske. Istega dne je bila še konferenca o tehnični izvedbi deportacij Slovencev in Srbov. Tu so potekali dogovori o začetku deportacij, začetnih in končnih železniških postajah, oskrbi in zavarovanju transportov. Dogovorili so se, da bodo prvi val s slovenske Štajerske 
začeli deportirati 7. junija ter da bodo do 1. julija prepeljali na teden po dva vlaka s po tristo izgnanci. Ko so govorili o deportaciji drugega vala, so zavezali hrvaško vlado, da pripravi v Zagrebu sprejemno taborišče. Za končno postajo tretjega vala so določili Zagreb. Sklepi konference $\checkmark$ Zagrebu so bili za izvajanje deportacij Slovencev zelo pomembni. Že naslednji dan sta nemški transportni oficir in vodstvo hrvaških državnih železnic seznanila ustrezne nemške, hrvaške in srbske ustanove $z$ voznim redom transportov. Vlaki naj bi vozili s postaje Rače-Fram in se ustavljali na večjih postajah, da bi izgnanci lahko dobili hrano in vodo. Ustavili naj bi v Celju, Zagrebu, Bosanskem Brodu, Doboju, Zenici, Sarajevu, Užicu, nato pa bi prispeli na končno postajo - Aranđelovac. 7. junija, ko je odpeljal prvi transport, so sklenili, da bodo nadaljnji transporti vozili s kolodvora v Mariboru in ne s postaje Rače-Fram. Tega dne so namreč dokončno popravili železniški most v Mariboru, ki ga je ob umiku razstrelila jugoslovanska vojska (Ferenc 1968, 225-241). Iz Maribora je tako odšlo 26 transportov, in sicer 7., 10., 13., 17., 20., 24. in 27. junija ter 1., 2., 3., 4., 5., 11., 12., 13., 14., 15., 16., 17., 18., 19., 20., 21., 23., 24. in 26. julija 1941. Nato so transporti odhajali iz Rajhenburga; teh je bilo sedem (Roš 1967, 15-16). Vsak transport je spremljalo sanitetno osebje, ki so ga sestavljali kar izgnanci. Ob izgnancih je bilo še ustrezno oboroženo spremstvo zaščitne policije.

$\vee$ noči s 6. na 7. junij 1941 so $v$ meljskem zbirnem taborišču nacisti poklicali določena imena. Poklicane so odvedli v poseben kletni prostor. Preostali v vojašnici $v$ tem času niso smeli ne na dvorišče ne na hodnike in tudi ne k oknom. Kljub temu se je kmalu razvedelo, da so kletni prostori polni ljudi in da na dvorišču čakajo tovorni avtomobili. Tudi $\vee$ mestu je vladal preplah, saj so to noč nacisti pobrali mnogo mariborskih družin. Šele popoldne so jetnike poslali na 16 tovornih avtomobilov, pokritih s šotorskimi krili, in jih odpeljali čez lesen dravski most, kar je pomenilo, da jih ne peljejo na sever. Da je bil transport namenjen na jug, so kmalu izvedeli tudi tisti, ki so ostali v vojašnici. Transport je štel 303 osebe, večinoma iz Maribora, le nekaj aretirancev je bilo od drugod. Kamioni so iz Maribora peljali do Slovenske Bistrice, kjer so ljudi premestili na vlak (Roš 1967, 82-83). Prvi transport z vlakom ni odpeljal iz Maribora, ker predora pri Slovenski Bistrici še niso popravili. To so storili 9. junija 1941, zato so naslednji transporti lahko odhajali iz Maribora. Po dveh dneh počitka v Aranđelovcu so izgnance odpeljali naprej v Jagodino. Tam so del izgnancev nastanili v domu gluhonemih, drugi del pa $v$ poslopju učiteljišča. Veliko se jih je zaposlilo zlasti $v$ tamkajšnji pivovarni. Iz mesta so mnogi odšli na podeželje ( $\mathrm{Fe}$ renc 1968, 241, 422-427).

Že 9. junija zvečer so v Melju poklicali naslednjo skupino, v kateri so bili Mariborčani, Celjani in podeželani. Nacisti so sestavljali drugi transport. Po polnoči so kamioni pripeljali še njihove družine. Snidenje $z$ družinami je bilo prisrčno, čeprav $v$ danih razmerah boleče. Tisti, ki 
so bili namenjeni za drugi transport, so čakali v kletnih prostorih. $\mathrm{Na}$ dvorišče so smeli le opoldne k delitvi kosila. Pred odhodom so jim $\checkmark$ taborišču ponovno prebrskali prtljago in kakšno dragocenost zadržali zase. Nato so morali po štirje $v$ vrsti $v$ oboroženem spremstvu odkorakati proti železniški progi. Tudi ta transport je bil namenjen $v$ Aranđelovac in je štel 303 osebe. Za razliko od prvega transporta so pregnanci tokrat že v Mariboru sedli na vlak in ne v Slovenski Bistrici. Drugi transport je prišel v Aranđelovac 12. junija, nato pa je nadaljeval pot proti Ćupriji. Neoborožen srbski žandar jim je ob njihovem prihodu dejal: »Zdaj ste svobodni ...« (Roš 1967, 88-91). V Ćupriji so izgnance nastanili pri družinah, nekaj pa v poslopju okrožnega sodišča. Zaposlovali so se v tamkajšnji tovarni sladkorja, veliko pa se jih je preselilo na podeželje ali v druga mesta (Ferenc 1968, 422-427).

Tretji transport v Srbijo je Maribor zapustil 13. junija. V njem so bili Celjani, Ptujčani in Mariborčani. Z njim so v Aranđelovac odpeljali tudi Meto Rainer (Roš, 1967, 101-105). Iz Aranđelovca so po počitku izgnance odpeljali v Paraćin. Izgnance so nastanili v nekaterih praznih poslovnih prostorih. Zaposlitev jim je nudila tamkajšnja steklarna. Ker pa za izgnance ni bilo dovolj delovnih mest, se jih je veliko že avgusta 1941 odpeljalo $v$ Zaječar, mesto ob bolgarski meji (Ferenc 1968, 423). Meto Rainer so izgnali skupaj z njeno mamo, ki je v izgnanstvu leta 1944 umrla. Rainerjeva je večino časa preživela v Zaječarju (Žebovec 2006 , 48). Po osvoboditvi je trdila, da slovenski učitelji v izgnanstvu niso mogli priti v prosvetno službo. Meta Rainer je tako v Čepurah dobila službo v živinorejski centrali kot statističarka (Rainer 1974, 286). Dejansko je bilo med izgnanci veliko profesorjev. Sprejemali so jih v službo na gimnazije, prošnje slovenskih profesorjev, da bi se zaposlili na osnovnih šolah, pa so oblasti odklanjale. Svoje odklonilno stališče so utemeljevale s tem, da se slovenski učitelji ne bi mogli dovolj povezati s podeželskim prebivalstvom, ker niso niti Srbi niti pravoslavne vere (Ferenc 1968, 427-428).

Četrti transport se je začel 17. junija z odhodom izgnancev iz meljske vojašnice na kolodvor. Na poti je izgnance molče opazovala množica ljudi. Ko je eden od njih skušal spregovoriti z nekom iz kolone izseljencev, so ga takoj prekinili stražniki z grožnjo, da bodo streljali. Množica je še bolj onemela, saj nihče ni želel tvegati in izreči česa obtožujočega ali bodrilnega. Ponovno ni nihče zagotovo vedel, kam gredo, vsi pa so upali, da se bodo po osvoboditvi slovenskega ozemlja vrnili (Roš 1967, 112). Tudi ta transport je peljal v Aranđelovac, od tam pa po dveh dneh počitka v Kruševac. Tam so bili izgnanci tri dni gostje mestnega prebivalstva, nato pa so jih razdelili po vaseh.

Peti transport je iz Maribora odpeljal 20. junija. Štiri dni kasneje je prispel $v$ Aranđelovac, od tam pa je odpeljal naprej v Đunis. Tudi tam so izgnance poslali $\vee$ različne kraje. Nadaljnjih transportov niso več ustavljali v Aranđelovcu, temveč so jih pošiljali kar na sedež tistega 
okraja, v katerem so nameravali nastaniti izgnance. Šesti transport je odpeljal aretirance 24. junija naravnost v Lazarevac. 2. julija 1941 je nova skupina izseljencev odšla v izgnanstvo, tokrat v Gornji Milanovac. 8. transport je odpeljal $z$ mariborskega kolodvora $v$ Užice in Užiško Požego. Tiste, ki so prišli v Užice, so nastanili $v$ barake nad mestom, kjer so ostali nekaj mesecev in septembra 1941 dočakali osvoboditev mesta. Izgnance, ki so prispeli v Užiško Požego, so nastanili v obrtni šoli in topniških lopah. Z 9. transportom je bila 2. julija izseljena Nada Gaborovič. Transport je izgnance odpeljal naravnost $v$ Čačak. Tam je ostalo le okrog sto ljudi, saj je večja skupina izgnancev odšla $v$ delavnice vagonov v Kraljevu (Ferenc 1968, 423-424). Družina Nade Gaborovič se je sprva selila iz kraja v kraj. Še najdlje so se zadržali v Guči. Gaborovičeva se je tukaj preživljala z delom na polju. Ob koncu leta 1944 so njo in druga dekleta poklicali iz Zveze komunistične mladine Jugoslavije (SKOJ). Gaborovičeva je poziv zavrnila z izgovorom, da se želi pripravljati na vrnitev $v$ šolo in čim prej nadoknaditi zamujena štiri leta. Marca 1945 se je zaposlila kot administratorka v Narodnem odboru v Guči. ${ }^{5}$ Med vojno se je izgubil rokopis njenega romana Beli jorgovan; v izgnanstvu je spoznala svojega bodočega moža (Žebovec 2007, 129). 10. transport je iz Maribora odpeljal 3. julija 1941 in izgnance pripeljal v Gružo ter Kragujevac (Ferenc 1968, 424).

Janka in Alenko Glazer so 4. julija 1941 z 11. transportom izselili v Aranđelovac v Srbijo (Ciril 1977, 11). Enajsti transport je izgnance odpeljal še v Preljino in Mladenovac (Ferenc 1968, 424). Glazerjeva hči Alenka je medtem $v$ izgnanstvu nadaljevala šolanje in $v$ Kragujevcu tudi maturirala. Poleg tega je $v$ izgnanstvu pomagala pri ustanovitvi ljudske knjižnice $v$ Aranđelovcu in jo je pred vrnitvijo domov vodila devet mesecev (Žebovec 2007, 201). Transport, izveden 4. julija, je bil zadnji, ki je odpeljal jetnike iz Maribora. Glazerjeva (2016) se spominja dva dni trajajoče poti; $v$ Aranđelovcu so jih posamezniki kljub pomanjkanju in težkim medvojnim razmeram lepo sprejeli.

S sprejemnih postaj v Srbiji so izgnane Slovence pošiljali v razne večje kraje: Jagodino, Ćuprijo, Paraćin, Užice, Kruševac, Lazarevac, Požego, Čačak, Gučo, Gružo, Kragujevac, Kraljevo, Valjevo, Trstenik, Varvarin. $\checkmark$ teh krajih so okrajni načelniki imeli nalogo, da skupaj z okrajnimi in občinskimi odbori za naseljevanje Slovencev razmestijo izgnance po svojih občinah. V vsak kraj naj bi prišla le ena ali največ dve družini. Večino izgnancev so oblasti porazdelile po vaseh, bilo pa je tudi nekaj večjih kolonij, npr.v Valjevu, Užicu, Paraćinu, Čačku.V njih so si izgnanci najprej izvolili odbor, ki je urejal in vodil kolonijo ter jo predstavljal pred oblastmi in drugimi ustanovami. Odbori so za tiste izgnance, ki so živeli v koloniji, organizirali skupne kuhinje in menze. Vzdrževali so jih s sredstvi, ki so jih v ta namen dobili od oblasti. Nekaj pomoči je iz-

${ }^{5}$ Pokrajinski arhiv Maribor, fond Gaborovič Nada 1936-2004, mapa 2. 
gnancem dajal slovenski Rdeči križ v Srbiji, ki je imel svoj sedež v Beogradu. Prek njegovega odbora je vodstvo Rdečega križa v Ljubljani večkrat obiskalo kolonije slovenskih izgnancev. Tudi srbski Rdeči križ si je prizadeval pomagati slovenskim izgnancem. Boljše zveze kot Rdeči križ je imela s Slovenijo t. i. slovenska socialna pisarna v nadškofijski palači v Beogradu. V njej so poleti 1941 ustanovili ilegalni odbor za pomoč slovenskim izgnancem. Odbor je začel z nabiranjem hrane, obleke, odej in drugih življenjskih potrebščin za izgnance, iskanjem služb in organizacijo sprejemanja in odpošiljanja pisem ter drugih pošiljk za izgnane Slovence. Toda ta odbor ni dolgo deloval. V Valjevu je bila največja in najaktivnejša kolonija. Njen odbor so izvolili že 11. julija 1941. Odbor je uvedel obvezno delo za moške in ženske, uredil skupno kuhinjo in dežurno službo. Zaradi vedno večje draginje je postajalo življenje v koloniji vse težje in so morali za hrano prodajati celo obleke in perilo. $V$ letu 1943 so kolonijo preimenovali v Združenje slovenskih izgnancev $v$ Srbiji, člane pa porazdelili po zasebnih hišah (Ferenc 1968, 421-426).

\section{Podoba izgnancev v leposlovju treh književnic}

Veliko književnikov je zapisalo svoje doživljanje izgnanstva med drugo svetovno vojno $v$ obliki novel, spominske proze in dnevniških zapiskov. Gaborovičeva je, poleg objave dnevnika, napisala roman, ki tematizira problematiko izgnanstva. Jesen brez poletja je roman, $v$ katerem je kot literarno snov uporabila konkretna doživetja in jih podprla z domišljijo. Vsebina romana se nanaša na obdobje med leti 1941 in 1945 in predstavlja družino, prisiljeno zapustiti dom in domovino. Že sam naslov romana pomenljivo izpostavi dejstvo, da je bilo poletje 1941 za izgnance izgubljeno oz. prelomno; preživeli so ga v meljski vojašnici in na poti v izgnanstvo. $O$ njem je Gaborovičeva zapisala: »Pisala sem knjigo še brez naslova; toda vsebina je bila $v$ meni tako izkristalizirana, da sem jo končno imenovala s pravim imenom: Jesen brez poletja. Nas, pregnance, zaznamovane $v$ vojni vihri, nismo mogli postaviti $v$ zaporedje letnih časov. Tako okrutna pomlad življenja za nas ni pomenila preraščanja $\checkmark$ poletje, zajela nas bo kar jesen« (Žebovec 2007, 129-130). Gaborovičeva se $v$ tem romanu spominja veselja in pomiritve med slovenskimi izgnanci ob novici, da odhajajo na jug: »Nekdo je pritekel kot otrok razigran v vagon z novico, ki nas je znenada oživila. Samo ne v Nemčijo, ne na sever! Kamorkoli drugam, le med Nemce ne! Obkrožili smo glasnika, ki nam je zatrjeval, da je slišal stražarje govoriti o Srbiji /.../«. Ob prihodu v Srbijo je voznik njihovega voza izrazil upanje, da bodo pri njih zadovoljni; Gaborovičeva je sicer odvrnila, da je domovina le ena, a je vseeno upala, da bodo $v$ novem okolju resnično deležni gostoljubja. Tako je $v$ spominu ohranila vrstnike v Srbiji: »Mladina se je prijateljsko zbližala z nami, ni veliko spraševala in opazovala, temveč nas je sprejela $v$ svojo sredo kot tovariše in vrstnike« (Gaborovič 1961, 114-125). 
Večina književnikov je izgnansko tematiko in motive upodobila $v$ pesmih, nekateri tudi $v$ celotnih pesniških zbirkah. Precej pesmi je $v$ času izgnanstva napisala Meta Rainer. Prva taka je pesem Morava, ki jo je napisala v letu 1941 v Ćepurah pri Paraćinu. Lirski subjekt opozarja na osamljenost in skrbi posameznika, izgnanca: »O Moráva, tiho tečeš, I še pozdrava mi ne rečeš, | ko po bregu tvojem hodim, | sama v težkih mislih blodim. V drugi polovici leta 1941 je zapisala besedilo pesmi Srbski materi - slovenski izgnanci. Pesem je nastala v Zaječarju in tematizira novo domovino izgnancev - Srbijo: »Zdaj še za nas ti je odprta roka, | ki so pognali nas v naročje tvoje, I sprejela si nas, revnega otroka«. Maja 1942 je $\checkmark$ Zaječarju nastalo besedilo pesmi Novorojenčku v izgnanstvu, ki je bila posvečena novorojenemu sinu tovariša Povha. V njej lirski subjekt izraža upanje na čimprejšnjo vrnitev $v$ domovino: "V pleničke bomo, dete, te povili, | te negovali in skrbno pazili, | dokler ne bomo te domov spremili. || $V$ domačem kraju mati, spet vesela, I s teboj se bo na bližnji grič povzpela, I ti čar slovenske zemlje razodela«. Prav tako v Zaječarju je spomladi leta 1943 Rainerjeva napisala pesem Pomladna elegija, leto kasneje pa še Malodušje. Slednja je bila po vojni objavljena v Savinjskem zborniku v Celju leta 1965. Ta pesem je, za razliko od besedila Novorojenčku v izgnanstvu, že manj optimistična: »Mesec se bledi ozira na zbegano čredo. | Dneve bodoče obseva mi upanje bledo, || ali iz gozda nespečna še sova skovika, | senca po tleh in po zidih strahove mi slika, || ura na steni počasi, brez volje, tiktaka. | Skrijem z rokami obraz. - Bog, kaj nas še čaka! \ V Zaječarju je nastalo tudi besedilo pesmi Kraljevica, in sicer v letu 1944 (Paternu 1997, 485-488).

V poeziji je svoja občutenja izpovedala tudi Alenka Glazer. Njena moč je $v$ upodabljanju tradicionalne ženske intime, $v$ intenzivnem občutju senzibilne odprtosti, prizadetosti in bolečine, ki preveva njene krhko stilizirane stvaritve. Strahove in tesnobo ob negotovi prihodnosti je izrazila v pesmi Groza pred tujim: „Čez reko čujem | boleče rjovenje | letala, | ko išce tal. | Napite veje | me s škrapljami namakajo. | Vsa mokra se zarivam mednje, | da me zakrijejo | neznanemu, strašljivemu. | V daljavi strel«. V sonetu Apnica pa se ženski lirski subjekt dotakne preizkušenj in bolečin v mladosti: »/.../Prvikrat po grdi | mladosti, ko lomila v bolečini | sem se, kot poka les v napeti žrdi, | so brez sledi izginili spominiu. Kot je Janko Glazer napisal pesem v spomin sinu Matiji, ki je 6. aprila 1945 kot partizan padel pri Brčkem $\vee$ Bosni, se tudi Alenka Glazer $\vee$ omenjenem sonetu dotakne bolečine ob spominu na izgubo: »/n zakipela bol je, se zgostila | $v$ bodeče razočaranje $v$ globini. || In ostra usedlina je ostala | $v$ dnu žgoče pekočine, sredi vrenja - I spomin na čase, ko bila sem skala. || Shladila se vročica je žarenja | in bridka zrnca sčasom so razpala. | Nezrušna vez pa spaja tri življenja«. Spomin na vojno vihro obudi tudi v pesmi Krvava sodba: »Težko z vdanostjo sprejemati udarce | v poravnavo za pozabljene pregrehe, | ki so zrušile nevidno ravnovesje | dobrega in zla« (Glazer 1968, 14-45). 


\section{Sklep}

Če upoštevamo spominske zapise in korespondenco pisateljic Nade Gaborovič, Alenke Glazer in Mete Rainer, lahko vidimo, da je večina ljudi z zaskrbljenostjo in nelagodjem pričakovala prihod nemškega okupatorja. Vse so ostale narodno zavedne in so se opredeljevale proti nacizmu. Ob aretaciji so jih prepeljali $v$ meljsko zbirno taborišče. Življenje v meljski vojašnici je bilo za vse težko in neprijetno; še najbolj zadovoljni so bili tisti, ki so prišli v taborišče tik preden je odpeljal njihov transport $v$ izgnanstvo. Zlasti s pomočjo spominov tistih, ki so bili v taborišču več dni ali celo več tednov, lahko začutimo napeto ozračje in nečloveške razmere, ki so vladale $v$ taborišču. Iz taborišča so ujetnike odpeljali $v$ izgnanstvo $z$ različnimi transporti. Že $v$ vojašnici so se pojavljala ugibanja, kam jih nameravajo odpeljati. Želeli so si, da bi vse glasnejše govorice o transportih v Srbijo bile resnične. Oddahnili so si, ko so ob začetku transporta videli, da jih ne peljejo na sever, v Tretji rajh. Srbija je zanje predstavljala odrešitev, saj so si bolj želeli oditi v izgnanstvo kot prenašati nevzdržne razmere v vojašnici. Književniki so bili torej prepričani, da se jim bo pri Srbih bolje godilo kot v domačem kraju v prisotnosti okupatorja, ki jim je iztrgal domove, prekinil družinske vezi ter jih zaprl v taborišče z nemogočimi bivalnimi pogoji. Eden od srbskih vojakov je ob prihodu transporta izgnancem zagotovil, da so sedaj svobodni.

\section{Viri in literatura}

Arhivsko gradivo

Pokrajinski arhiv Maribor. Fond Gaborovič Nada 1936-2004.

Literatura

Biber, Dušan. 1966. Nacizem in Nemci v Jugoslaviji 1933-1941. Ljubljana: Cankarjeva založba.

Buttolo, Franca in Peter Svetina. 1996. Slovenska književnost. Ljubljana: Cankarjeva založba.

Ciril, Stani. 1977. »Življenjepis Janka Glazerja«. Zgodovinski časopis 1/2 (48): 5-12.

Ferenc, Tone. 1968. Nacistična raznarodovalna politika v Sloveniji v letih 19411945. Maribor: Obzorja.

Ferenc, Tone. 1997. Okupacijski sistemi na Slovenskem 1941-1945. Ljubljana: Modrijan.

Filipčič, Milan. 2003. Bili so uporni : zaprti, izgnani, ubiti, na suženjskem delu, $\checkmark$ koncentracijskih taboriščih. Ljubljana: Koordinacijski odbor žrtev nacifašističnega nasilja pri GO ZZB NOB Slovenije. 
Gaborovič, Nada. 1961. Jesen brez poletja. Maribor: Založba Obzorja.

Gaborovič, Nada. 2003. Dnevi, leta. Maribor: Mariborska literarna družba.

Glazer, Alenka. 2016. Spomini. Dostopno na: https://4d.rtvslo.si/arhiv/ prof-alenka-glazer/174388693/

Godeša, Bojan. 1995. Kdor ni z nami, je proti nam. Ljubljana: Cankarjeva založba.

Hartman, Bruno. 1983. »Kulturni tokovi v Mariboru in njegovem zaledju med vojnama«. Časopis za zgodovino in narodopisje 1-2 (54): 232-247.

Milharčič Hladnik, Mirjam. 2020. »Življenjske zgodbe. Terezija Černelič: Prisilne migracije in otroška izkušnja izgnanstva med drugo svetovno vojno $v$ ustnem pričevanju«. V Doba velikih migracij na Slovenskem, ur. Aleksej Kalc, Mirjam Milharčič Hladnik, Janja Žitnik Serafin, 428-438. Ljubljana: Založba ZRC.

Ostrovška, Milica. 1981. Kljub vsemu odpor I, II. Maribor: Obzorja.

Paternu, Boris. 1997. Slovensko pesništvo upora. Ljubljana: Znanstveni inštitut Filozofske fakultete.

Potočnik, Dragan. 2003. Kulturno dogajanje v Mariboru v letih 1918-1941. Maribor: Litera.

Rainer, Meta. 1974. »Spomin na okupacijo«. V Odprta srca, ur. Moma Markovič. Maribor.

Rainer, Meta. 2004. Modri spominček. Žalec: Medobčinska matična knjižnica.

Roš, Fran. 1967. Slovenski izgnanci v Srbiji 1941-1945. Maribor: Obzorja.

Škerl, France. 1952/1953. »Nacistične deportacije Slovencev v letu 1941«. Zgodovinski časopis 1 (6/7) : 768-797.

Žebovec, Marjeta. 2007. Slovenski književniki, rojeni od leta 1920 do 1929. Ljubljana: Karantanija.

Žnidarič, Marjan. 1997. Do pekla in nazaj : nacistična okupacija in narodnoosvobodilni boj v Mariboru 1941-1945. Maribor: Muzej narodne osvoboditve.

Tjaša Markežič

Prva gimnazija Maribor

Slovenija

tjasa.markezic@prva-gimnazija.org

\section{NA PUTU IZGNANSTVA SA SLOVENAČKIM KNJIŽEVNICAMA: OD DONJE ŠTAJERSKE DO SRBIJE}

Nemačka okupacija dela slovenačke teritorije u aprilu 1941. godine obeležila je živote mnogih Slovenaca. Okupator je došao u Donju Štajersku sa ciljem da tu teritoriju što pre germanizuje. Svakog ko bi mogao da ometa taj plan nacisti bi proterali sa okupiranih teritorija. Među 
žrtvama bile su i slovenačke književnice, koje su svojom profesijom, književnim stvaralaštvom i nacionalnom svešću ometale okupatora u njegovim namerama. U cilju organizacije progona, nacisti su najpre osnovali migracioni štab i njemu potčinjena tela, a zatim su organizovali sabirne logore po raznim krajevima Donje Štajerske. U Mariboru je deo kasarne „Melje“ pretvoren u logor za prognanike, odakle su oni poslati dalje u razna mesta po Srbiji.

Ključne reči: nacizam, Donja Štajerska, slovenački književnici, koncentracioni logor „Melje“, progonstvo

Tjaša Markežič

The First Maribor Grammar School

Slovenia

tjasa.markezic@prva-gimnazija.org

\section{TRACING THE JOURNEY OF EXILE OF SLOVENIAN FEMALE WRITERS: FROM LOWER STYRIA TO SERBIA}

The German occupation of a part of the Slovenian territory in April 1941 was a breaking point in the lives of many people. The occupation forces came to Lower Styria with the goal to Germanize the territory. The Nazis intended to banish all those who could stand in the way of their plans. The victims also included Slovenian female writers who interfered with the plans of the occupation forces through their profession, writing and national awareness. At first, the Nazis established a migration headquarters in Maribor and subordinate agencies to organize deportations; later, they established assembly camps at different sites in Lower Styria. In Maribor, a part of the barracks at Melje was reorganized to serve as a camp for the exiled, who were transported to different locations in Serbia.

Keywords: Nazism, Lower Styria, Slovenian writers, assembly camp at Melje, exile

Primljeno / Prejeto: 22.06. 2020

Prihvaćeno / Sprejeto: 04. 12. 2020 